\title{
The Relationship between Teamwork and Organizational Trust $^{\mathrm{i}}$
}

\author{
Musab Işılk \\ Atatürk University, Postgraduate, Faculty of Economics and Administrative Sciences, Department of Business \\ Administration, Erzurum/Turkey, \\ M. Kürşad Timuroğlu, $P h D^{i i}$
}

Atatürk University, Assistant Professor, Faculty of Economics and Administrative Sciences, Department of labour economics and industrial relations, Erzurum/Turkey,

\section{Yussuf Aliyev}

Atatürk University, Master's graduates, Faculty of Economics and Administrative Sciences, Department of Business Administration, Erzurum/Turkey

\begin{abstract}
The aim of this study is to investigate the relationship between teamwork and organizational trust. In the implementation section the data from the survey of 250 workers is employed in call centers in Erzurum by using relevant statistical methods. Consequently, it is found that there is a positive and significant relationship between teamwork and organizational trust. Thus, the hypothesis of the study is supported as it was expected. Besides, it is found that there are positive and significant relationships between communication, openness to innovation, participation-trust in teamwork and organizational trust, trust in management, trust in co-workers, and trust in workplace.
\end{abstract}

JEL Classification: D01, D12, D23

Keywords: Teamwork, Organizational Trust, Comunication, workplace

\section{(C) 2015 Published by SSBFNET}

\footnotetext{
${ }^{i}$ The data used in this study was obtained from the master thesis titled "The Relationship Between Teamwork And Organizational Trust in Call Centers".

ii Corresponding Author
} 


\section{Introduction}

Nowadays, the each day rising importance of the human factor in every field has a remarkable issue. This is because of the fact that no processes are kept going on without the valuable contributions of an experienced individual. Businesses are aware that without the human factor it is impossible to be successful in the global competition or even to survive in today environment. With this awareness businesses now give an attention to activities by which they can keep, motivate or give the sense of importance to the competent individuals who can work towards company's goals and objectives.

Without any doubts, one of such activities is a teamwork which is now unavoidable for any organization. That is, contemporary firms see the teamwork activities as a fundamental element in running the business. In fact, the trends towards teamwork activities arise from the idea that they can allow to fully utilize the skills of the workers during the restructuring of firms in order to gain a competitive advantage. Comparing to organizations that has traditional departments or similar structures in their design, the companies, which are oriented at teamwork activities, can experience such benefits as the achievement of flexibility, the acceleration in decision making, task distribution and focusing on organizational goals as well as the increase in the motivation and synergy among team members. However, teamwork can bring some negative results to organizations too. Teamwork is not effective if the goal and vision of the team is not clear, the responsibility of team members is above their knowledge and competence, the time is not enough, there is dissatisfaction of promotion and reward system, there is too much control over the team actions, top management does not give enough support to the team and there is not a climate of a participation and trust inside the team. Because of this, teamwork should be fostered and backed with factors by which it can function successfully and productively. These factors include the ideal level of independence of team members; the efficient leadership system; high use of knowledge and technology; proper team training and open communication, adequate delegation of power, the shared goals, values and vision among team members.

Furthermore, if there is a factor, by which interpersonal relations can sustain at very high levels and by which organizations can survive for a very long time, it, of course, is trust. Trust occurs through past positive impressions that humans or organizations has left. In this case, in the eyes of the employee trust evolves when the organization protects the interests of workers or, at least, does not behave in a way by which it can harm those interests. As for the organization, trust is evaluated in terms of the self-sacrifices, identification and commitment towards the organizational goals of its employees.

The aim of this work is to investigate the relationship between teamwork and organizational trust. In this regard, teamwork and organizational trust concepts will be explained in depth. After the place will be given to a survey results conducted in a call-center located in Erzurum, Turkey. The data deducted from the survey is analyzed using different statistical methods. In the end, the positive and significant relationship between teamwork and organizational trust is found. 


\section{Literature Review}

\subsection{Teamwork}

\subsubsection{Team}

Teams are made up by two or more people who come together to achieve a common goal, who are assigned to complete a special task and who cooperate with each other. Teams can be considered as structures, which are designed with the decisions of persons, who possess special knowledge or skills in order to carry out a job in a given time and where there is too much workload (Dyer, 1985: 285-287).

Katzenbach and Smith (1993: 43) define teams as a group of a small number of people, who commit themselves towards the common goals, whose performances are adjusted towards the group targets, who can communicate openly with each other and who have complementary skills. From these definitions it is obvious that there are 4 main features of teams that scholars concentrate on. These are common goals and commitment, performance targets, complementary skills and a mutual accountability.

What differentiates a team from other work groups is that its leader share the responsibilities of a group, there is a mutual responsibility in addition to the individual responsibilities, there is a collective focusing on work, in group meetings it is allowed to have open-end debates for problem-solving or to bring an innovation and performance appraisal is made according to the work accomplished collectively. All of these characteristics can create a synergy in the team (Kaztenbach and Smith, 2005:162-171).

In this context, the most salient properties of teams are as followed:

1. Teams are designed to accomplish a task and are results-oriented.

2. Team members are independent in the work they fulfill.

3. Feedback method is used in teams.

4. $\quad$ There is a synergy among team members (Margerison, 2001: 120).

\subsubsection{Teamwork}

Although teamwork is considered as a notion popular in modern global business world, its foundations can be said to be made at Socrates times when in a joint work authors came up with seven principles that describes what "the spirit of friendship" is. These seven principles include establishing a dialogue, the belief in changeability of ideas, not being in conflict with others, not intervening during others' talks, listening carefully, expressing the thoughts in a clear manner and being honest. Trust developed with the help of these doctrines contributed to the establishment of the bases of modern physics by joint works of ancient philosophers (Michalko, 1993: 59-62).

At this point, the following can be said about teamwork: teamwork is not a financial, a strategic or a technologic factor. Still, because teamwork has the same attributes and is as rare as these factors it can be characterized as a means to get the competitive advantage for a business (Lencioni, 2002: 8). Teamwork creates a set of persons who are 
dependent on each other and who share the responsibility for a common goal (Valsecchi, Wise, Mueller and Smith, 2012: 289). Payne, defined teamwork as a means and process by which team members tend to work together in a harmonious, productive and effective way in order to accomplish tasks and achieve team goals (Chen, 2009: 19).

On the other hand, teamwork is also important due to the increase in effectiveness it can bring and because it resembles the structure whereby its members work in a planned manner both collaboratively and communicatively, the work is well organized and there is a regular exchange of information, ideas and products. For this reason, organizations that want to reduce the costs and increase the effectiveness prefer to use teamwork (Hardingham, 1997: 9).

In this article, the teamwork dimensions are taken as characteristics of effective teams especially in call-centers. These dimensions consist of communication, openness to innovation and participation-trust.

Communication is the most important dimension which contributes to the emergence of trust and which develops bonds as inside the team as between managers and organization. This dimension also promotes members to listen to each other and advance mutual knowledge, fosters cooperation, participation, the sense of belongingness to the group and consensus among team members and, lastly, allows for creative and qualitative results to emerge (Weiss, 1993: 14-16).

Openness to innovation in teamwork is necessary to encourage the initiatives of presenting new and improved ways doing the things, to approve and support such practices, to cultivate a feeling of taking a common responsibility of the team tasks and a desire to do anything possible for overall team success, to take important decisions on innovations and to achieve effective results (Henry, 1998: 57).

Participation-trust dimension shapes the psychological framework in which unexpected incidents such as establishing an environment accepted to be threating for individuals involved are overcome by motivating and strengthening team members when making decisions. Team members create an environment where ideas and different views are not rejected, all participators feel that they are competent for accomplishing the tasks and perceive that there is no place for political behaviors. Additionally, participation-trust facilitates team members to participate in decision-makings through influence, relationship and information sharing in order to bring forward new and improved approaches to the way work is done and to make more investments with such decisions (Anderson and West, 1998: 237).

\subsection{Organizational Trust}

\subsubsection{Trust}

Although the notion of trust has very extensive place in a related literature and is being a topic of many disciplines such as psychology, sociology, philosophy, economy, management, marketing, history, political science, anthropology and industrial psychology, the common characteristic that these disciplines approach to the concept is related to the belief or positive expectations (Paliszkiewicz, 2011: 3). 
Overall, all the different viewpoints on trust can be grouped in three main categories: personality theorists' view of trust who consider the concept from human's personal differences which are affected by social and developmental factors, economists' and sociologists' view of trust who see the concept as a an institutional phenomenon and social psychologists' view of trust who define this phenomena as a creation or disruption of the sense of trust among individual or group parties (Lewicki and Bunker, 1996: 115-116).

At this point trust explains the extent to which two parties are willing to ascribe decent intentions about each other and the extent to which one party is trusted by another in terms of the words said or actions made (Cook and Wall, 1980: 39-52). Trust is the concept that indicates the extent a person is trusted and the extent that other party is influenced from the words, actions or decisions of the party who is supposed to be trusted (McAllister, 1995: 24-59). Trust occurs, without taking into an account the observation or control over one party, when a trusting party voluntary accepts others' actions to some degree on the basis of the expectation she/he has about special benefits that actions will bring (Mayer, Davis and Schoorman, 1995: 709-734). When both parties believe they will reciprocally fulfill their obligations, behave in a way appropriate to the spoken words and act in a fair way even when there are opportunities in favor of self-interests (Zaheer, McEvily and Perrone, 1998: 141-159). In addition to this, trust is created when the involved parties have such traits as sufficiency, clarity in actions, relevance and reliability and when these traits are coherent with common goals, values, norms and beliefs (Shockley-Zabalak, Ellis and Winograd, 2000: 35-49).

All these definitions of trust have 8 elements in common: fairness, openness, consistency in behaviors, clarity, ability to keep secrets, functional skill, business understanding and common sense. Because these elements affect the creation and the development of trust, it is impossible for trust to emerge without these aspects (Butler et al., 1991: 650).

Due to these different points of views the dimensions of trust also differ from one theorist to another. For example, Lewis and Weigert (1985: 967, see also McAllister, 1995: 25; Chowdhury, 2005: 310) put forward that trust can be separated into (1) cognitive trust based on consciousness that focuses on "good excuses" to believe others and relies on personal thoughts about others and (2) emotional trust, which is mainly based on emotions, that accentuates on creating emotional bonds among people by developing mutual involvement and relevance. In the same vein, Mayer, Davis and Schoorman (1975: 710) categorized trust's dimensions into two main factors: expediency that has huge effect on trust and sufficiency that stresses upon cognitive aspects of trust. Cook and Wall (1980: 40) explored the topic from a little bit different angle, pointing out that trust includes believing in others' propensity of being trustworthy and believing in others' abilities.

\subsubsection{Organizational Trust}

Organizational trust has a vital importance in such aspects as globalization, workplace diversity, an increase in awareness about cultural differences, a necessity to improve democracy levels in the workplace, international networks, complex partnerships, information technology and distribution of responsibility in decision-making in different situations or processes. That is, organizational trust refers to the positive expectations from individuals about 
their behaviors and intentions by taking into consideration multiple organizational members' organizational roles, relations, experiences and commitments (Shockley-Zalabak et al., 2000: 35).

Organizational trust is studied from two different angles: interpersonal and institutional. Interpersonal trust refers to the positive expectation of one party, who needs to make decisions while being dependent and vulnerable, from other party's actions (Hosmer, 1995: 382). In the other hand, institutional trust is mainly about widespread rules shared among society's members, who expect right, honest and collaborative behaviors to increase (Fukuyama, 1995: 25). At last, the definition of trust, which incorporates both interpersonal and institutional viewpoints, can be made as follows: trust refers to the willingness of one party to be vulnerable against others via that party's concentration on others' attitudes such as sufficiency, clarity, relevance and reliability (Mishra, 1996: 266). Both points of view on trust presume that the concept has such characteristics as uncertainty, dependence, impact and expectation of definite behaviors. These are inherent for both views (Bromiley and Cummings, 1996: 303-305).

Beyond these points of view Gabarro (1978: 292) defined organizational trust as a degree of making sure that in a relationship between two individuals there is clarity in actions: one person's feelings will not be related to malicious and groundless actions of another. The author also described organizational trust as an extent to which one person expects another to show pure-minded demeanors in a given situation. Conversely, Baier (1986: 238) defined organizational trust as reliance upon one's willingness and ability to draw back rather than to do a disservice to what others carefully appointed her or him. According to Mishra and Morrissey (1990: 445) organizational trust is a belief cherished by workers that managers will keep and fulfill own promises.

In this context, it should be mentioned that in the relevant literature there are three major dimensions of organizational trust that come to the fore: trust in management, trust in co-workers and trust in workplace (Cook and Wall, 980: 3952; see also, Nyhan and Marlowe, 1997: 614-635; McAllister, 1995: 24-59).

Trust in management refers to the workers' voluntariness to act in a consistent way useful for the organization interests even when the managers do not have control over actions and activities of the workers (Mayer et al., 1995: 714). This dimension also refers to the ability of workers to express work-related problems easily and not being afraid to encounter negative consequences (Fulk et al., 1985: 304).

Trust in workplace refers to confiding in organization and perceiving its support and can be defined as a degree of the belief that organization will keep its promises. In businesses, where resources are utilized in an effective way and where there is an efficient reward system, employees will trust in the workplace because they will feel that are being appreciated and are being valued (Nyhan, 2000: 95). On the other hand, although there is a strong relationship between trust in management and trust in workplace, both dimensions have different antecedents and outcomes. Trust in workplace is focused on global values that affect the organization such as perceived organizational support and organizational justice whereas trust in management takes into account such values as manager's capabilities, respectability and helpfulness. While trust in workplace increases organizational commitment and affects turnover, trust in management influences personnel satisfaction and encourages innovative behaviors (Tan et al., 2000: 242). 
Finally, trust in co-workers derives from two subtype top and bottom relationships: a belief that both parties are reliable and a belief that both parties are highly gifted in the work assigned to them. So, by considering these two subtypes and taking into account interpersonal trust this dimension concerns workers' expectations that involved parties will be interested in, helpful, honest and fair to each other. Additionally, trust in co-workers is related to the belief that co-workers possess such characteristics as competency, fairness, reliability and ethical behavior (Yeh, 2007: $54-56)$.

\subsection{The Relationship between Teamwork and Organizational Trust}

In this chapter of the article there is a list of some relevant works that researched the relationship between teamwork and organizational trust from different angles important to the focus of the current study. In accordance to the findings of these works hypotheses of this study are created.

In their work titled "The Experience and Evolution of Trust: Implications for Cooperation and Teamwork" Jones and George (1998: 531-546) developed a model in which they proposed some assumptions about how organizational trust is developed and how organizational trust affects collaboration and teamwork. Authors stated that trust in organizations is created in accordance with the organizational members' values, attitudes, states of mind and emotions. They put forth conditional and unconditional trust forms that are criterions for how trust evolves in progress of time. Conditional trust indicates that parties will continue to interact as long as behavioral expectations of each other are met. Unconditional trust specifies that one party's reliability could be provided by confidence and belief in other party's values. Researchers found that for conditional trust to occur it is only necessary to have an open communication among team members. At the same time it is found that unconditional trust plays more important role in the resurgence of communication (team members are tightly committed to each other) and in ensuring the cooperation and the success of a team. Consequently, writers argued that conditional and unconditional forms of trust can bring a competitive advantage to organizations by fostering interpersonal collaboration and teamwork effectiveness. Some important points to this work can be derived from Jones and George's study. Conditional trust can be considered as a factor which contributes positively to communication and teamwork. Yet if conditional trust is transformed into unconditional trust, communication and collaboration are possibly to be at the highest levels. Thus, there will be high levels of trust and success in teamwork.

In the article called "The Role of Trust for The Functioning of Teams in Organisations" Costa (2002: 1-15) aimed to investigate the relationship between trust and team's/organization's effectiveness and performance. For this purpose author carried out a survey on 395 members of 112 teams that work in 3 social care institutions. In order to prove that trust is multi-dimensional construct the researcher took the characteristics of trust such as propensity to trust, trustworthiness (the perception of trusting person about the degree of readiness, willingness and ability of trusted person to meet performance requirements), collaborative and supervisory behavior as its dimensions. One of the important results of the analyses is that trust has positive effect on team performance. Another result of the study suggests that trust has positive effects on team effectiveness factors such as satisfaction in team and commitment to the relations and negative effects on stress. It was proved that trust is multi-dimensional construct and that trust has 
significant effects on team performance and effectiveness. The importance of Costa's research for this article is that beyond trust in management, trust in co-workers and trust in workplace other dimensions of trust have effects on teamwork too. This is the indication of how intertwined are $t$ teamwork and organizational trust concepts.

Hakanen and Soudunsaari (2012: 1-10) wrote an article named "Trust in Building High Performing Teams" where they examined how trust should be managed in order to create high performance teams. For this purpose researchers conducted a longitudinal survey (at two different periods of time) in 3 different institutions that operate in health sector. One of the objectives of the study was to observe the effects of teamwork and trust on the achievement of global success in multicultural organization via providing high levels of communication among the organization's networks. Firstly they found that trust plays an important role in the formation of teamwork. Within this context, other findings of the study show that collaboration and teamwork can increase the level of trust and affect the overall team performance. Also writers found that collaboration and teamwork contribute to a good communication. Another finding suggests that for teamwork's effectiveness to be at intended levels it is essential to bring together such team members who may come from any place of the world and whose knowledge and skills are good and, thus, reliable. So, organization's trust on its members' knowledge and skills can play an important role in providing high levels of success in teamwork. Finally, the significant and positive relationship between trust and team performance was revealed.

In their work with the title of "Building Team Trust: A Study in The Asian Context" Collins and Chou (2013: 181188) examined whether trust in traditional and virtual teams influences team's productivity at different levels. The distinction between traditional and virtual teams is related to whether team members are in the same or various environments, the usage level of information technology and the density and limitedness of supervision. According to writers in different workplaces the type of trust that will bring effectiveness to a business changes in accordance with the design of teams. From standpoint it is stressed that for traditional teams interpersonal trust plays more important role whereas for virtual teams institutional trust is essential. In this context researchers conducted two-step halfempirical study. In the first quantitative research 29 university students were distributed into the teams of 3 or 4 members in order to achieve a given objective. After that, researchers conducted interviews on these subjects at the beginning of the project and after 3 months. In the end of the projects subjects were also surveyed. In the second qualitative study students from different countries were distributed into self-managing virtual teams that consisted of 5 or 6 members. With the help of information technology it was made sure that members of these virtual teams share online information with each other. In the end of the given projects investigators conducted interviews on the subjects. Results from quantitative study suggest that interpersonal trust affects team's productivity while results from qualitative study show that team's productivity is affected by institutional trust. Generally the conclusion from the findings of Collins and Chou's study useful for this article can be derived. That is, while in traditional teams trust in co-workers is the most important factor for team's success and effectiveness, in virtual teams trust in management and trust in workplace have more important role for an effective teamwork. 
In their article with a title "Trust and Distrust in Teamwork: Is Unconditional Trust or Optimal Trust Essential for Performance?" Erdem and Ozen (2000: 633-643) conducted an empirical research that studied the relationship between trust and performance in teamwork. Researchers attempted to find out whether unconditional trust or ideal level trust is necessary for team's performance evaluation. In this vein, 279 employees from 10 different firms were subjected to a survey. Originally subjects were distributed into 50 teams with 5 people in each team. In the analysis of data collected from these surveys, ideal level trust considered to exist at four different levels. This type of trust was supposed to have impacts on high levels of performance in teamwork. The four levels of ideal level trust consists of "productive trust" that creates efficient collaboration among team members, "unproductive trust" that causes the team's performance to decrease due to excessive solidarity among team members, "productive distrust" that develops learning-type behaviors in team and "unproductive distrust" that creates negative expectations among team members and lessens collaboration. Results of the study suggest that productive trust has the most important effect on the development of a belief in team member' each other skills or honesty. It also influences willingness for collaboration and team performance by creating a confidence in team leader's fairness. Other factor that can contribute to the increase of team performance is productive distrust, which ensures that all the decisions in a team are taken according to the consensus among team members and brings to the forefront unconditional trust rather than ideal level trust.

In conclusion, from the review of literature and the perspective of this study the following hypotheses are made:

$\mathrm{H}_{1}$ : There is a positive relationship between teamwork and organizational trust.

$\mathrm{H}_{1 \mathrm{a}}$ : All of the dimensions of teamwork (participation-trust, openness to innovation and communication) have a positive relationship with organizational trust.

$\mathrm{H}_{1 b}$ : All of the dimensions of teamwork (participation-trust, openness to innovation and communication) have a positive relationship with trust in in management.

$\mathrm{H}_{1 \mathrm{c}}$ : All of the dimensions of teamwork (participation-trust, openness to innovation and communication) have a positive relationship with trust in co-workers.

$\mathrm{H}_{1 \mathrm{~d}}$ : All of the dimensions of teamwork (participation-trust, openness to innovation and communication) have a positive relationship with trust in workplace.

\section{Research and Methodology}

\subsection{The Purpose and Method of the Research}

The main purpose of this study is to explore the relationships between teamwork and organizational trust in call-centers. In this parallel, other sub purposes of this study are to examine demographic variables of workers in callcenters, to determine the dimensions of both teamwork and organizational trust and to prove or disprove above written hypotheses.

The importance of this research is that although lots of researchers have studied team work and organizational trust as the main topics there is an insufficient number of studies that investigated the relationship between these two 
constructs and the present study attempts to fulfill this gap. Furthermore, this study can give some light to the management of call-centers for whom teamwork is essential for the overall success.

The population of the research is composed of "Global Knowledge" (Global Bilgi) call-centers' employees who work in Erzurum, Turkey. Call-centers have become very popular because they can offer faster and more quality services in many sectors of economy. Erzurum is the investment place in terms of call-centers and consequently offers lots of employment opportunities. Moreover, call-centers can be said to be among the first organizations which utilize and need teamwork practices. Thus, the research is thought to be on teams in call-centers. At this point, the sample of 1600 workers population is counted as 387 employees. This number has $\% 95$ levels of reliability and $\% 5$ margin of error. Because workers at these call-centers had time constraints and there were problems of allowance to distribute questionnaires, only 305 questionnaires were distributed and from this number only 250 questionnaires were collected back. The rate of return of questionnaires is $\% 82$.

\subsection{The Research Questionnaire and Survey}

In the research the questionnaire method of survey conduction was implemented. The reliability levels of questionnaires are calculated using Cronbach Alpha Reliability Coefficient. According to this calculation all the forms in questionnaires have high levels of reliability. To determine the relationship between teamwork and organizational trust Pearson Correlation Analyses was used. In the first part of the questionnaire subjects were asked to answer 5 demographic variables questions. These demographic variables include gender, education level, age, experience and income. In the second part of the questionnaire there were 20 items related to teamwork and 22 items related to organizational trust. In the reliability analyses of 20 items of teamwork scale, $7^{\text {th }}$ question (There is a lot of exchange of information in the team) of the scale was removed because it was loaded to more than one factor. On the other hand, the reliability analyses of 22 items of organizational trust scale showed that $16^{\text {th }}$ question (I believe that workers are treated fairly in this workplace) lowered the overall reliability level of the measurement. So it was decided to remove this item as well.

Teamwork scale was comprised of participation-trust, openness to innovation and communication subscales. The items for the first two subscales were borrowed from Anderson and West's (1998) "Team Climate Inventory" questionnaire (Anderson and West, 1998: 235-258) whereas the last subscale items were adapted from Hoegl and Gemunden's work (Hoegl and Gemünden, 2001: 435-449). The scale of organizational trust was created using three subscales too. The items of trust in management and trust in workplace subscale were adapted from Nyhan and Marlowe's (1997) "Organizational Trust Inventory" (Nyhan and Marlowe, 1997: 614-635), whereas the subscale of trust in co-workers contains items from Cook and Wall's (1980) "Interpersonal Trust at Work" scale (Cook and Wall, 1980: 39-52). These scales use 5 choices $(1=$ Absolutely Disagree, $2=$ Disagree, $3=$ Neutral, $4=$ Agree, $5=$ Absolutely Agree) Likert-type measurements. 


\section{The Research Findings}

\subsection{Findings about Demographic Variables of Subjects}

124 subjects that comprise the sample are males (\% 49.6) whereas others are females (\% 50.4). Age limits for the sample are as follows: 28 subjects are in 20-25 (\% 35.2) age limit, 88 subjects are in $26-29$ (\% 33.6) age limit, 84 subjects are in 30-33 (\% 15.6) age limit, 39 subjects are in 18-21 (\% 11.2) age limit and 11 subjects are in 34 and more (\% 4.4) age limit. 5 workers have primary education (\% 2), 40 - high school education (\% 16), 118 - pre-licensing education (\% 47.2), 81 - undergraduate education (\% 32.4) and 6 - postgraduate education (\% 2.4). 89 workers have the experience of 1 year and below (\% 35.6), 123 - between 2 and 5 years ( $\% 49.2)$ and 38 - between 6 and 9 years (\% 15.2) in the call-center subject to this study. Lastly, 69 workers have an income of 700-1000 TL (\% 27.6), 138 - 10001300 TL (\% 55.2), 36 - 1300-1700 TL (\% 14.4), 4 - 1700-2000 TL (\% 1.6) and 2 - beyond 2000 TL (\% 0.8).

\subsection{Findings from Factor Analyses}

At first, "Kaiser-Meyer-Olkin (KMO) and Bartlett's Test" analyses were conducted in order to find out whether it is applicable to do exploratory factor analysis on the data. If $\mathrm{KMO}$ value is more than 0.60 and Bartlett's Test's results are significant then the data is suitable for factor analysis. KMO value between 0.90 and 1.00 is considered to be excellent, whereas KMO value between 0.80 and 0.89 is accepted as very good (İşcan and Sayin, 2010: 206).

For the teamwork scale KMO Measure of Sampling Adequacy is 0.951 and Bartlett's Test of Sphericity, which indicates whether it is possible to derive significant factors from the research data, is $3.705,363$ at $\mathrm{p}<0.000$. Both numbers are at satisfactory levels. 3 factors derived from teamwork scale explain $\% 70.07$ of the total variance. First factor was called communication. It has an Eigenvalue of 4.711 and explains $\% 24.797$ of the total variance. Openness to innovation is the second factor and it determines the willingness of workers to be innovative at work. It has and Eigenvalue of 4.382 and explains \%23.062 of the total variance. Participation-trust is the last, third factor derived from the factor analysis of teamwork scale. This factor has an Eigenvalue of 4.220 and explains \%22.210 of the total variance.

For the organizational trust scale KMO Measure of Sampling Adequacy is 0.945 and Bartlett's Test of Sphericity is $4.672,430$ at $p<0.000$. Both values are at satisfactory levels. 3 factors that were derived from organizational trust scale explain \% 72.66 of the total variances. The first factor - trust in management - has an Eigenvalue of 5.308 and explains \%25.28 of the total variance. The second factor is trust in co-workers and it refers to workers' perception of a development of strong organization by confiding in each other. This factor has an Eigenvalue of 5.131 and it explains $\% 24.44$ of the total variance. Finally, the third factor derived from analysis was trust in workplace. It has an Eigenvalue of 4.820 and explains $\% 22.95$ of the total variance.

\subsection{The Relationship between Teamwork and Organizational Trust}

Correlation analysis is the statistical method which measures the level and degree of the relationship between two variables. The correlation coefficient is represented wit " $r$ " letter. This coefficient can take values between -1 and 
+1 . If the value is close to -1 , then there is a negative relationship, and if the value is close to +1 , then the relationship is negative. If the coefficient is somewhere near 0 , it means that there is no significant relationships between variables. In social sciences if the " $r$ " value is found to be between 0 and 0.3 , then there is a low level relationship; if the " $r$ " value is between 0.3 and 0.7 , then there is a medium level relationship; and, if the " $r$ " value is between 0.7 and 1 , then there is a high level relationship between the variables (Saruhan and Özdemirci, 2005: 139).

At the next page Table 1 shows the correlation coefficients between the factors of teamwork and organizational trust as well between teamwork and organizational trust in general. From the table it can be seen that there is a positive relationship $(\mathrm{r}=0.750)$ between teamwork and organizational trust at \%99 level of significance. This relationship means that an increase in the workers' perception on teamwork will occur with an increase in the workers' perception on organizational trust.

When analyzing the table in terms of the strength of relationship communication factor of the teamwork scale has a stronger relationship with organizational trust $(\mathrm{r}=0.737)$ than any other factors. Nevertheless, other factors of teamwork scale - openness to innovation and participation-trust - have strong relationships with organizational trust. Correlation coefficients for these relationships are $(\mathrm{r}=0.638)$ and $(\mathrm{r}=0.620)$ respectively.

Table 1: The Relationship between Teamwork and Organizational Trust

\begin{tabular}{|c|c|c|c|c|c|c|c|c|}
\hline & $\mathbf{1}$ & $\mathbf{2}$ & $\mathbf{3}$ & $\mathbf{4}$ & $\mathbf{5}$ & $\mathbf{6}$ & $\mathbf{7}$ & $\mathbf{8}$ \\
\hline Communication (1) & 1 & & & & & & & \\
\hline Openness to Innovation (2) &, $700^{* *}$ & 1 & & & & & & \\
\hline Participation-Trust (3) &, $647^{* *}$ &, $746^{* *}$ & 1 & & & & & \\
\hline Trust in Management (4) &, $627^{* *}$ &, $525^{* *}$ &, $469^{* *}$ & 1 & & & & \\
\hline Trust in Co-Workers (5) &, $669^{* *}$ &, $553^{* *}$ &, $596^{* *}$ &, $531^{* *}$ & 1 & & & \\
\hline Trust in Workplace (6) &, $607^{* *}$ &, $613^{* *}$ &, $541^{* *}$ &, $759^{* *}$ &, $486^{* *}$ & 1 & & \\
\hline Teamwork (7) &, $870^{* *}$ &, $911^{* *}$ &, $899^{* *}$ &, $602^{* *}$ &, $677^{* *}$ &, $665^{* *}$ & 1 & \\
\hline Organizational Trust (8) &, $737^{* *}$ &, $658^{* *}$ &, $620^{* *}$ &, $905^{* *}$ &, $764^{* *}$ &, $889^{* *}$ &, $750^{* *}$ & 1 \\
\hline
\end{tabular}

${ }^{*} \mathrm{p}<0.05,{ }^{* *} \mathrm{p}<0.01$

The findings from the correlation analyses show that the relationship between the workers' perception on teamwork and organizational trust is significantly and positively directed. It can be interpreted from this that any increase in the level of perception on teamwork will bring an increase in the level of perception on organizational trust with itself and vice versa. These results along with the significant relationships between the factors of each scale suggest that both measurements have a high validity. 


\subsection{The Effect of Teamwork and Its Dimensions on Organizational Trust}

In order to strengthen the findings from correlation analyses regression analyses were conducted as well. In these analyses teamwork's dimensions (communication, openness to innovation and participation-trust) were taken as dependent variables and organizational trust was taken as independent variable.

As it can be seen from Table 2 teamwork's dimensions explain \%59 of the change in total variance of organizational trust with a significance level of $\% 99\left(\mathrm{R}^{2}=0.592\right.$ and $\left.\mathrm{F}=119.205^{* *}\right)$.

Furthermore, communication dimension has a greater effect on organizational trust $\left(\beta=0.506^{* *}\right)$ than openness to innovation $\left(\beta=0.192^{*}\right)$ and participation-trust $\left(\beta=0.150^{*}\right)$ do. Thus, it is possible to state that the increasing of the level and quality of communication in teams at call-centers will, in the same time, affect positively the increase of the level of workers' perception on organizational trust.

Table 2: The Effect of Teamwork's Dimensions on Organizational Trust

\begin{tabular}{|c|c|c|c|}
\hline \multirow{2}{*}{ Dependent } & \multicolumn{3}{|c|}{ Organizational Trust } \\
\cline { 2 - 4 } & $\boldsymbol{\beta}$ & $\boldsymbol{t}$ & $\boldsymbol{p}$ \\
\hline Communication &, $506^{* *}$ & 8,571 & 0,000 \\
\hline Openness to Innovation &, $192^{*}$ & 2,834 & 0,005 \\
\hline Participation - Trust &, $150^{*}$ & 2,364 & 0,019 \\
\hline $\mathbf{R}^{\mathbf{2}}$ & &, 592 & \\
\hline Adjusted $\mathbf{R}^{\mathbf{2}}$ & & \multicolumn{3}{|c|}{} \\
\hline $\mathbf{F}$ & \multicolumn{3}{|c|}{$119,205^{* *}$} \\
\hline
\end{tabular}

${ }^{*} \mathrm{p}<0.05,{ }^{* *} \mathrm{p}<0.01$

From the findings of the analyses of survey data it is possible to say that all hypotheses of this research can be accepted. Together with the findings from correlation analyses, these findings suggest that the perception on teamwork affects the perception on organizational trust and especially communication related practices could be implemented in order to increase the workers' perception on organizational trust.

\section{Conclusion and Recommendations}

Without any doubts, human being is aware that in order achieve her/his aims in the life she/he needs to closely follow global developments. The same situation can be attributed to organizations for which it is an obligation to follow up such changes in order not only to achieve the organizational goals and be successful but also to continue their existence. As such, with the time going on, organizations recognize that they need to adapt to fast changing environmental conditions and implement strategies that will bring a competitive advantage in a very quick and 
effective way. One of the requirements which can provide these advantages is the workforce that is qualified, has a high level of knowledge and skills and can adapt to the changing environment very quickly.

However, it is not enough for organizations to be just aware of the requirement for such a qualified workforce. They also need to make the organization attractive as for outside potential workforce as for the employees who are actually employed there so that these workers will not quit their jobs. Those organizations, which can succeed in this, will gain such advantages as high performance, productivity, effectiveness and competitive advantage. So, in order to find such a qualified workforce that will bring these advantages, many organizations implement different strategies, which take into consideration the workers' qualities and needs, provide an organizational culture suitable for workers identification with the organization and enhance workers' motivation. Among these strategies teamwork and organizational trust could be listed as the most popular and effective ones. This study concentrated on these concepts in detail. As it was mentioned before these constructs are related to each other and both of them have been investigated in many different areas of businesses. These include education, health, communication, banking industry and callcenters.

In order to investigate the relationship between these concepts survey research was conducted in one call-center located in Erzurum. The sample that participated to the survey consisted of slightly more women than men and the majority of participants were $22-25$ years old. Furthermore, most of the subjects had a high school education, $2-5$ years of work experience in the organization and an income of $1000-1300 \mathrm{TL}$. These characteristics of the call-center are important for a creation of teamwork, especially among young employees. Also, generally the high level of subjects' education affected their responses to the questionnaires by amplifying the levels of teamwork and organizational trust and their dimensions. According to the correlation analyses there is a positive relationship between teamwork and organizational trust at \% 99 significance level. Additionally, teamwork dimensions (communication, openness to innovation and participation - trust) were determined to be positively related to organizational trust dimensions (trust in management, trust in co-workers and trust in workplace). Results suggest that teamwork plays an increasing role for organizational trust and with the increase of the levels of workers' perception on teamwork their levels of trust in management, co-workers and workplace increase too.

The following suggestions from these findings can be made:

Organizations must provide participation and trust climate for its workers because it can enhance the team members' confidence in each other, create an environment where there is a more open communication and a better information sharing among team members, promote the workers' feelings to use personal skills and abilities for the sake of organizational goals, enhance workers' motivation to participate more actively and without any fear in decisionmaking, problem-solving and presenting new ideas. Beyond this, the high level of participation and trust in teams can both develop communication, openness to innovation and effectiveness in teamwork and strengthen the workers' levels of organizational trust.

Developing a climate open to innovations can greatly benefit teams for various reasons as it can bring such an environment for team members where they would be successful in presenting different perspectives for solving any 
problems encountered as a team. Also, such an environment may promote team members to implement already experienced methods and processes or be creative in finding out the better solutions for problems. On the other hand, in teams open to innovations members can enhance their own skills and believe that are valued in the organization due to their contributions to team success. This, in turn, can develop a ground for organizational trust to increase. Of course, employees are keen to trust a work environment where they perceive that their thoughts are valued and which necessitates workers to make an effort for the overall success. So, workers want to work in such a workplace. Among the most important factors that can provide this environment are communication and collaboration. Thus, organizations need to pay attention to these topics. An environment of trust among team members as well as among managers and organizations is beneficial for the organizational performance, the quality of outputs and the organizational competitive advantage. It also may build trust and collaboration among employees by improving the quality and rate of communication.

Communication should not be negligible issue as for an effective teamwork as for an organization as a whole. Thanks to communication the productivity and performance of teamwork can be increased. In the same time communication is a necessary pre-condition for organizational trust to occur. It can establish an environment of interaction and collaboration among team members and improve employee's knowledge, skills and expertise.

\section{References}

Anderson, N. R., \& West, M. A. (1998). "Measuring climate for work group innovation: Development and validation of the team climate inventory". Journal of Organizational Behavior, 19, 235-258.

Baier, A. (1986). "Trust and antitrust". Ethics, 96, 231-60.

Bromiley, P., \& Cummings, L. (1996). “The organizational trust inventory”. In R. Kramer \& T. Tyler (Eds.), Trust in organizations: frontiers of theory and research (pp. 302-330). California: Thousand Oaks.

Butler, J. K. (1991). "Toward understanding and measuring conditions of trust: Evolution of the conditions of trust inventory". Journal of Management, 17(3), 643-663.

Chen, Y.-C. (2009). Organizations' Characteristics Influence On Teamwork And Organizational Commitment In Taiwan. (Ph. D. Dissertation). Pennsylvania: The Pennsylvania State University.

Chowdhury, S. (2005). "The role of affect- and cognitions-based trust in complex knowledge sharing". Journal of Managerial Issues, 17 (3), 310-326.

Collins, N., \& Chon, Y.-M. (2013). "Building team trust: A study in the Asian context". The Journal of American Business Review, 1 (2), 181-188.

Cook, J., \& Wall, T. (1980). "New Work attitude measures of trust, organizational commitment and personal need non-fulfillment”. Journal of Occupational Psychology, 53 (1), 39-52.

Corazzini, R. (1977). “Trust as a complex multi-dimensional construct”. Psychological Reports, 40, 75-80.

Costa, A. C. (December 2002). "The Role of Trust for The Functioning of Teams in Organisations" [Report]. European Academy of Management Conference, Berlin.

Dyer, J. L. (1984). “Team research and training: A state of the art review”. Human Factors Review, 285-323. 
Erdem, F., \& Özen, J. İ. (2000). "Takım Çalışmalarında Güven ve Güvensizlik: Performans için Koşulsuz Güven Mi, Optimum Güven Mi?" [Trust and Distrust in Teamwork: Is Unconditional Trust or Optimal Trust Essential for Performance?] \{Report\}. 8. Ulusal Yönetim ve Organizasyon Kongresi: Bildiriler $\left[8^{\text {th }}\right.$ National Management and Organization Congress: Reports] (Nevşehir), 25-27 May 2000, (pp. 633-645). Kayseri: Erciyes Üniversitesi.

Fulk, B. A. P., \& Barr, S. H. (1985). "Trust-in-Supervisor and perceived fairness and accuracy of performance evaluations". Journal of Business Research, 13, 301- 313.

Fukuyama, F. (1995). Trust: The social virtues and the creation of prosperity. New York: Free Press.

Gabarro, J. J. (1978). "The development of trust, influence and expectations". In A. Athos \& J. Gabarro (Eds.), Interpersonal behavior: Communication and understanding in relationships (pp. 290-303). Englewood Cliffs, New Jersey: Prentice Hall.

Hakanen, M., \& Soudunsaari, A. (2012). "Trust in building high performing teams". Technology Innovation Management Review, June, 1-10.

Hardingham, A., (1997). Takım Çalışması (1. bs.) [Teamwork in Practice $\left(1^{\text {st }}\right.$ ed.)] (Translators: Aksu Bora \& Onur Cankoçak). Ankara: İlkkaynak Kültür ve Sanat Ürünleri. (1995).

Henry, J. E., \& Hartzler, M. (1998). Tools for Virtual Teams: A Fitness Companion. Milwaukee, WI: ASQ Quality Press.

Hoegl, M., \& Gemünden, H.G. (2001). "Teamwork quality and the success of innovative projects: A theoretical concept and empirical evidence". Organization Science, 12, 435-49.

Hosmer, L. T. (1995). "Trust: The connecting link between organizational theory and philosophical ethics". Academy od Management Review, 20(2), 379-403.

Işık, M., (2014). "The Relationship Between Teamwork And Organizational Trust in Call Centers". Master Thesis, Ataturk University Institute of Social Sciences.

İşcan, Ö. F., \& Sayın, U. (2010). “Örgütsel Adalet, İş Tatmini ve Örgütsel Güven Arasındaki İlişki” [“The Relationships between Organizational Justice, Job Satisfaction and Organizational Trust"]. Atatürk Üniversitesi I.I.B.F. Dergisi [Atatürk University Journal of Economics and Administrative Sciences], 4 (24), 195-214.

Jones, G. R., \& George, J. M. (1998). "The experience and evolution of trust: Implications for cooperation and teamwork". The Academy of Management Review, 23 (3), 531-546.

Katzenbach, J., \& Smith, D. (1993). The Wisdom of Teams: Creating the High Performance Organization. New York: McKinsey \& Company.

Katzenbach, J. R., \& Smith, D. K. (2005). "Discipline of teams". Harvard Business Review, 83 (7/8), 162171.

Lencioni, P. M. (2002). The five dysfunctions of a team. New Jersey: Jossey-Bass.

Lewicki, R. J., \& Bunker, B. B. (1996). "Developing and maintaining trust in work relationships". In R. M. Kramer, \& T. R. Tyler (Eds.), Trust in organizations, frontiers of theory and research (pp. 114-139). Thousand Oaks, Ca: Sage.

Lewis, D. J., \& Weigert, A. (1985). “Trust as a social reality”. Social Forces, 63 (4), 967-985. 
Margerison, C. J. (2001) "Team management, team competence". Team Performance Management: An International Journal, 7, 117-122.

Mayer, R. C., Davis, J. H., \& Schoormann, F. D. (1995). "An integrative model of organisational trust". Academy of Management Review, 20 (3), 709-734.

McAllister, D. J. (1995). "Affect- and cognition-based trust as foundations for interpersonal cooperation in organizations". Academy of Management Journal, 38 (1), 24-59.

Michalko, M., (30 December 1993). "Einstein's teamwork secret". Training, 60-61.

Mishra, A. K. (1996). "Organizational responses to crisis: The centrality of trust". In R. M. Kramer \& T. R. Tyler (Eds.), Trust in organizations: Frontiers of theory and research (pp. 261- 287). Thousand Oaks, CA: Sage.

Mishra, J., \& Morrissey, M. A. (1990). "Trust in employee/employer relationships: A survey of West Michigan Managers”. Public Personnel Management, 19(4), 443-486.

Nyhan, R. C., \& Marlowe, H. A. (1997). "Development and psychometric properties of the organisational trust inventory”. Evaluation Review, 21 (5), 614-635.

Nyhan, R. C. (2000). "Trust and its role in public sector organizations". The American Review of Public Administration, 30 (1), 87-109.

Paliszkiewicz, J. O. (2011). "Trust management: Literature review". Warsaw University of Life Sciences Management, 6, 315-331.

Shockley-Zalabak, P., Ellisi K., \& Winograd, G. (2000). "Organizational trust: What it means, why it matters?". Organizational Development Journal, 18 (4), 35-49.

Tan, H. H., \& Lim, A. K. H. (2008). "Trust in coworkers and trust in organizations". The Journal of Psychology, 143 (1), 45-66.

Valsecchi, R., Wise, S., Mueller, F., \& Smith, C. (2012). "The practice of teamwork in health industry call centers". Employee Relations, 34, 288-305.

Weiss, D. H. (1993). Başarılı Ekip Oluşturma [How to build high-performance teams]. (Translator: Erhan Tuskan). İstanbul: Rota Yayınları. (1936).

Yeh, T.-J. (2007). Leadership Behavior, Organizational Trust, and Organizational Commitment Among Volunteers in Taiwanese Non-Profit Foundations. (Unpublished Ph. D. Dissertation). San Antonio, TX: University of the Incarnate Word.

Zaheer, A., Mcevily, B., \& Perrone, V. (1998). "Does trust matter? Exploring the effects of interorganizational and interpersonal trust on performance". Organization Science, 9 (2), 141-159. 